DOI https://doi.org/10.30525/978-9934-588-91-4-34

\title{
DECENTRALIZATION IN UKRAINE AS A CHALLENGE TO POLITICAL CHANGES
}

\begin{abstract}
Kozlov K. I.
Candidate of Sciences on Public Administration, Associate Professor, Associate Professor at the Department of Political Science and Philosophy Kharkiv Regional Institute of Public Administration of National Academy of

Public Administration attached to the Office of the President of Ukraine Kharkiv, Ukraine

Pilhun M. V.

Post-Graduate Student at the Department of

Regional Development and Local Self-Government

Kharkiv Regional Institute of Public Administration of National Academy of

Public Administration attached to the Office of the President of Ukraine

Kharkiv, Ukraine
\end{abstract}

Social and political transformations of Ukrainian society, which became as a result of the Revolution of Dignity, led to real changes in approaches to the development of the policy of the authority's decentralization in Ukraine. It should be emphasized that the reform of local self-government, which had to lead to the decentralization of authority relations, was one of the most desirable reforms expected by a large number of Ukrainians.

The consequence of such expectations was the approval, by the Prescription of the Cabinet of Ministers of Ukraine dated 01.04.2014 № 333-r, the Concept of local self-governance and territorial power reforming in Ukraine [1].

A detailed analysis of the problems that needed to be solved gradually allowed us to formulate quite clearly the purpose of the Concept, namely:

- to define the trends, mechanisms and terms and terminations of establishing the effective local self-government and territorial organization of power to create and maintain complex living environment for citizens, providing high quality and affordable public services, establishing the institutions of direct democracy, meeting the interests of citizens in all life spheres on corresponding territory, reconciling the interests of the state and local communities [1].

The main innovations of the Concept include:

- distribution of powers between local governments on the principle of subsidiarity and endowment of communities with the widest possible range of powers; 
- liquidation of state administrations and creation instead of state representations with exclusively control-supervisory and coordination, instead of executive functions;

- transfer of executive functions from local administrations to executive bodies of councils of the appropriate level;

- association of territorial communities capable of resolving issues of local significance independently or through local self-government bodies;

- clarification of the three-level system of administrative-territorial organization of Ukraine - region, district, community with the prevalence of local self-government;

- creation of favorable legal conditions for involving the population in management decisions and development of forms of direct democracy;

- granting territorial communities the right to dispose of land resources within their territory, to unite their property and resources within the framework of cooperation of territorial communities.

Another step towards the implementation of the policy of decentralization of power should be the introduction of rather controversial, and sometimes contradictory, provisions of the Act «On Amendments to the Constitution of Ukraine on Decentralization of Power», which provides:

- for administrative supervision over the observance of the Constitution and laws of Ukraine by local self-government bodies, coordination of the activities of territorial bodies of central executive bodies, it is proposed to introduce the institute of prefects. The Prefect is appointed and dismissed by the President on the proposal of the Cabinet of Ministers.

It is envisaged that the prefect may suspend the acts of local selfgovernment on the grounds of their inconsistency with the Constitution or laws of Ukraine with a simultaneous appeal to the court.

In addition, the bill stipulates that if the head of the community, community council, district, regional council adopts an act that does not comply with the Constitution and threatens to violate state sovereignty, territorial integrity or national security, the President shall suspend the relevant act at the same time appeal to the Constitutional Court, temporarily suspends the powers of the head of the community, the composition of the community council, district, regional council and appoints a temporary state commissioner.

- reforming the system of administrative-territorial organization, principles of management of territorial communities and their material and financial support.

In turn, the Venice Commission praised the amendments to the Constitution of Ukraine in terms of decentralization, but recommended two changes, in particular regarding the powers of the President in terms of dismissal of elders and the number of categories of administrativeterritorial units.

Currently, the bill has been withdrawn by the President of Ukraine. 
In turn, we must recall that there are several types and sorts of decentralization, they are:

1. Political decentralisation is the transfer of political power and decision-making authority to sub-national levels such as elected village councils, district councils and state level bodies. Where such transfer is made to a local level of public authority that is autonomous and fully independent from the devolving authority, devolution takes place.

2. Fiscal decentralisation involves a level of resource reallocation to local government which would allow it to function properly and fund allocated service delivery responsibility, with arrangements for resource allocation usually negotiated between local and central authorities. The fiscal decentralisation policy would normally also address such issues as assignment of local taxes and revenue-sharing through local taxation and user and market fees.

3. Administrative decentralisation involves the transfer of decisionmaking authority, resources and responsibilities for the delivery of selected public services from the central government to other lower levels of government, agencies, and field offices of central government line agencies. The most radical form of administrative decentralisation is devolution, with local government having full responsibility for hiring/firing of staff and assigning authority/responsibility for carrying out tasks. De-concentration is the transfer of authority and responsibility from one level of the central government to another, with the local unit accountable to the central government ministry or agency which has been decentralised. Delegation, on the other hand, is the redistribution of authority and responsibility to local units of government or agencies that are not always necessarily branches, or local offices of the delegating authority, with the bulk of accountability still vertically directed upwards towards the delegating central unit [3, p. 4].

At the same time, it should be emphasized that local elections in Ukraine on October 25, 2020 should be held under the new version of the Constitution.

This is due to the fact that:

- first, it is necessary to provide for the constitutional legality of the existence of united territorial communities, which would become an element of the system of local self-government;

- secondly, it is necessary to solve the problem of the status of local state administrations, because today it is not clear the situation in which the head and deputy heads of local administrations are politicians, and their subordinates are civil servants (two different planes political and administrative combination in one body); 
- thirdly, in general it is necessary to approve the administrative (managerial) component of administrative-territorial units. After all, it is illogical for local state administration, district council and council of a united territorial community to exist at the same level of government (for example, district).

These issues are relevant and, in fact, their solution, in the process of decentralization, will overcome the challenges of political changes in Ukraine.

\title{
References:
}

1. Про схвалення Концепції реформування місцевого самоврядування та територіальної організації влади в Україні. Кабінет Міністрів України; Розпорядження, Концепція від 01.04.2014 № 333-p. URL: http://zakon5.rada.gov.ua/laws/show/333-2014-p. (дата звернення: 21.10.2020 p).

2. Президент Володимир Зеленський відкликає законопроєкт про внесення змін до Конституції щодо децентралізації влади. URL: https://www.ukrinform.ua/rubric-polytics/2857013-zelenskij-vidklikaeproekt-zmin-do-konstitucii-sodo-decentralizacii-op.html (дата звернення 22.10.2020 p).

3. Concept Paper on Decentralisation and Local Governance. Decentralisation and local governance: Module 1: Definitions and Concepts. 2007. 25 p.

DOI https://doi.org/10.30525/978-9934-588-91-4-35

\section{УКРАЇНСЬКЕ ГРОМАДЯНСЬКЕ СУСПІЛЬСТВО: ДО ОЦІНКИ НИНІШНІХ СПРОМОЖНОСТЕЙ ТА ПЕРСПЕКТИВ РОЗВИТКУ}

\author{
Корнієвський О. А. \\ доктор політичних наук, професор, \\ головний науковий співробітник \\ Національного інституту стратегічних досліджень \\ м. Київ, Украӥна
}

Перспективи сталого демократичного розвитку української державності обумовлюються не лише політичною еволюцією владних інститутів, а й насамперед - можливостями формування активного та високоорганізованого громадського сектору. Останнім часом дедалі помічаємо більшає ознак того, що він переживає черговий вирішальний 